\title{
Laos and the Belt and Road Initiative
}

\section{An Interconnector Helping the Chinese Needs?}

\section{VÖRÖS ZOLTÁN \& PONGKHAO SOMSACK}

\begin{abstract}
The paper intended to report on the growing activity and presence of China in its Southeast Asian neighbour, Laos, with a particular focus on the ongoing railway construction within the Belt and Road Initiative scheme. Beijing is using the $\mathrm{BRI}$ as a key momentum to increase its regional presence beside its already relevant investor and donor-role in the region. Within this context, Laos is essential for the East Asian giant because of its geographic location. It offers the possibility for China to make a physical connection with Thailand, Cambodia, Malaysia and even Singapore. Lao PDR can also benefit from the Chinese presence. Given its own limited financial capacities and infrastructure funds, these investments can turn Laos from a landlocked to a land-linked country. This in turn should contribute to lower costs of transport and logistics and could even help international and internal tourism, thus benefitting the whole economy. Linking the Lao capital of Vientiane with Kunming in China is under construction and scheduled for completion in 2021. This project is just the first phase; once fully completed, the railway will definitely serve as a significant economic route between China and Southeast Asian countries. But many questions were raised regarding who will gain the most benefits from this railroad project and how Laos can avoid the so-called 'debt trap'. The research paper sought to investigate advantages and disadvantages of Chinese infrastructure projects in Laos and how Vientiane can deal with these challenges in order to accrue more benefits from China's economic expansion in the region. Besides looking at the consequences from the Lao perspective, we focused on the Chinese benefits as well; how a completed railway connection can change China's position within the region and further strengthen its role within Southeast Asia.
\end{abstract}

Keywords: PR China, Laos, BRI, ASEAN, railway, debt trap, connectivity

\section{Introduction}

The $21^{\text {st }}$ century is widely perceived as the century of Asia - the period in which PR China gains significant economic influence in different parts of the world. China is not only one of the top investors and donors, but also plays an important role 
in infrastructure development in Asian countries, particularly in the Lao PDR. At the moment, China is using the Belt and Road Initiative as a key momentum to increase its regional presence and, at the same time, as a symbol of cooperation, openness and equal opportunities. The possible impact of the initiative generated global interest because of its powerful platform to boost economic growth and regional cooperation based on the concept of connectivity. The initiative seeks to strengthen infrastructure, trade, and investment links between China and some 65 other countries, representing collectively over $30 \%$ of the world's GDP, $62 \%$ of the global population, and $75 \%$ of known energy reserves (World Bank, 2018).

Within BRI, six economic corridors have been designed to link countries in different regions through new roads, railways, ports and pipelines all aimed at boosting connectivity and reducing non-tariff barriers to trade in Eurasia and Africa, with China as the hub (Liu, Pagano, Sánchez, \& Tapiero, 2018). So far, the Chinese investments have concentrated mainly on infrastructure development, energy and mining, ranging from a railway project in Kenya to hydropower projects in Cambodia. In the case of the Lao PDR, Beijing is also interested in the construction of infrastructure.

Laos already has a close relationship with its northern neighbor. China is its second largest trading partner, the largest foreign investor, and the largest aid provider of Lao PDR while the country is the third largest destination of China's investments among ASEAN states (Tuo, Hui, \& Zhongxia, 2018). While hopes are high on the Laotian side about the future cooperation, the authors wish to highlight that, like all the other Southeast Asian countries, Laos is also aware of the fact that they can't separate themselves from Chinese growth and power. The goal of the country should be to understand how they can live together with the Asian Giant, while benefiting from their presence.

The paper intends to describe the Lao interest towards the BRI followed by the introduction of the geographical and geopolitical position of Laos. Of the many Chinese investments, the focus will be on the China-Laos Railway. It is also important to look at how local citizens, experts and politicians think about China and the Initiative in order to understand all the considerations of such investments, especially in the case of Laos, where the realization of the hoped for benefits is still questionable. Beside the threats of such investments (and financial conditions), we are going to talk about the Chinese position and also about 'Connectivity' - a keyword for future Lao infrastructure projects. Finally, at the end we try to formulate a few recommendations as well.

\section{Why is Laos Interested in the BRI?}

First of all, the Initiative is aligned with the Lao government's policy of turning itself from a landlocked to a land-linked country, which could contribute to lower costs of transport and logistics for export products. The BRI also complies with the Lao National Socio-Economic Development Plan for 2016-2020, the National Development Strategy (2016-2025) and the Vision of Lao PDR until 2030. The main goal of Lao PDR is to graduate from the Least Developed Country Status by 2024 and become upper middle-income by 2030 . 
Since 1986, Lao PDR implemented an open-door policy aimed at developing (a controlled) market economy to finance the country's infrastructure development and also to boost economic growth through attracting FDI. While there is an increase in investments, most of it still arrives into the resource sector and China became the biggest foreign investor in the country. "Capital inflows from Chinese foreign direct investment (FDI) to Laos accounts for 25.2 per cent of the total FDI of the country. Chinese investments in Laos are mostly in the resource-related sector, such as mining and hydropower, which two sectors constituted more than 70 per cent of total Chinese investment. From 2005 to 2018, China had over 840 projects in Laos, with a total investment of over 11 billion US dollars" (Phommouny, 2019: 184).

Apart from the FDI, Beijing plays an important role in the trade relations of Laos as well. According to Comtrade, the value of Laos' export to China rose from 1.54 billion USD in 2018 to 1.67 billion USD in 2019 and further growth is expected. Meanwhile, the imports from China also increased and by 2019, Laos ended up with a small trade deficit: while in 2018 Chinese export to Laos was 1.28 billion USD, in 2019 it was 1.68 billion USD. The export products from China to Laos include electronic equipment, machinery, iron, steel and vehicles. Conversely, Laos dominantly exports natural resources and edible fruits (Comtrade, 2020). As we'll see, there still is potential for the country regarding trade opportunities with China by developing the infrastructure between the two countries. Through the BRI projects this Lao dream can become a reality.

There is another push factor for Laos: tourism. The upgraded infrastructure can benefit the internal mobility of tourists and, of course, it can help the visits of the Chinese tourists as well: in 2012, only 200,000 Chinese tourists visited Laos rising to more than a million in 2019 (Xinhua, 2020).

Eventually, Laos believes that the BRI can help them to address their geographic disadvantages through improved infrastructure connectivity since Beijing is actively interested in the Pan-Asia Railway Network, also known as the Kunming-Singapore railway - a concept already coined by the British and French colonial powers. The network is planned for two ${ }^{2}$ routes out of which the central route would link Kunming of Southwest China, Laos, Thailand, Malaysia and Singapore. Once completed, the mixed conventional/high-speed railway will serve as a significant economic corridor between China and the region and possibly will further promote Laos-China bilateral trade cooperation in a number of sectors, notably the service industry, processing, logistics, ecological agriculture, catering and light industry.

\section{The Geographical and Geoeconomical Position of Laos}

Due to its strategic and geographical position, Laos can serve as a bridge between China and ASEAN member states and can benefit from transit services. The country enjoys political and social stability, there are no ethnic or religious conflicts, creating a suitable and favorable site for investments and businesses (Tuo et al., 2018: 19). Laos is also abundant in natural resources, due to its huge potential for hydropower development, Laos plans to turn itself into the "battery of Southeast Asia" (Globe, 2018) by exporting electricity to the rest of the region. The country has a young society, with nearly $60 \%$ of the population under 25 - providing a possibility for future (skilled and equipped) labor force. 
However, there are limitations as well that come from its geographical position. Being a mountainous and landlocked country with poor infrastructure, economic development faces obstacles. The geographic barrier and the lack of conventional infrastructure makes it difficult for Lao products to compete with others in international markets due to the high costs of transportation. Surveys found that the cost of logistics in Laos is twice higher than that of other ASEAN countries. ${ }^{3}$ Even though the major roadways have been paved over the past few years, most of the nation is still only accessible through unpaved roads.

Besides, the country's institutional capacity remains weak, lack of transparency and the presence of corruption still defines the state. Due to the high percentage of unskilled labourers, Laos needs to immediately upgrade the quality of education and develop the skills of its young population. The agricultural sector represents $70 \%$ of employment, but the growth of this sector is very slow due to low productivity and old-fashioned farming methods (McGrain, 2014). Laos is ranked the $73^{\text {rd }}$ most vulnerable country to climate change (particularly floods, droughts and typhoons), due to the fact that it relies too much on the extraction of climate-sensitive natural resources to sustain the economic growth of the country (WFP, 2017).

A final, but important obstacle to overcome is the unexploded ordnance from the Second Indochina War. Over 500,000 bombing missions dropped more than two million tons of ordnance from 1964 to 1973 . About $30 \%$ of the bombs failed to detonate (UN, 2015).

Even though the government enacted and amended laws to attract more foreign investments to Laos, the investment climate in the country has not been improved. In 2019, Laos was ranked $154^{\text {th }}$ among 190 economies in the World Bank Ease of Doing Business annual ratings. Whereas based on how easy it is to start a business, the country was ranked $181^{\text {th }}$ (World Bank, 2019).

\section{The BRI in Laos: The China-Laos Railway}

The Belt and Road Initiative is of great importance in promoting economic cooperation between Laos and China. Since the launch of the initiative in 2013, a number of development projects have been started and implemented. These include the railway, the Boten-Mohan Economic Cooperation Zone, a satellite project (Lao Sat1), an expressway from Vientiane to the Chinese border, hydropower projects and connected grid network constructions. These are the most relevant development projects which not only create job opportunities and increase revenue for Laos, but also bring extensive benefits to the long-term development of Laos as well as providing stable dynamics for economic cooperation between the two countries.

The railway project is part of the Pan-Asia Railway Network, connecting the southern mainland of China with Southeast Asian nations through Laos. Built under the Belt and Road Initiative, the Vientiane-Kunming link is the first modern railway line in Laos which will eventually stretch towards Thailand and Malaysia before ending in Singapore. For China, the railroad, which reflects Beijing's ambitions to access seaports in ASEAN countries, is a significant step closer to their future dreams (MYHSR, 2017). For Laos, the railway connectivity will help the government to 
realize its decades-long aspirations of serving as a land bridge for the region. Laos wants to improve its infrastructure in a move to better connect with the rest of the region and expedite the process of economic development. Using Chinese technological standards and Chinese equipment, the China-Laos railway is not only a model cooperation project promoted by top leaders in Laos and China, but it is also an interconnectivity infrastructure project implemented between China and ASEAN countries. Given that the China-Laos railway is the central route for the $\mathrm{BRI}$ in the Southeast Asia region, the construction of this railroad project in Laos started in 2016 despite the fact that the construction of other rail lines in Malaysia and Thailand are still in question. The construction is scheduled for completion in 2021 , by the end of 2019 , around $70 \%$ of the construction was completed. Built by Chinese contractors, the 5.95 billion USD railway goes through the mountainous region in northern Laos and requires many tunnels and bridges.

Figure 1

The Pan-Asia Railway Network ${ }^{4}$

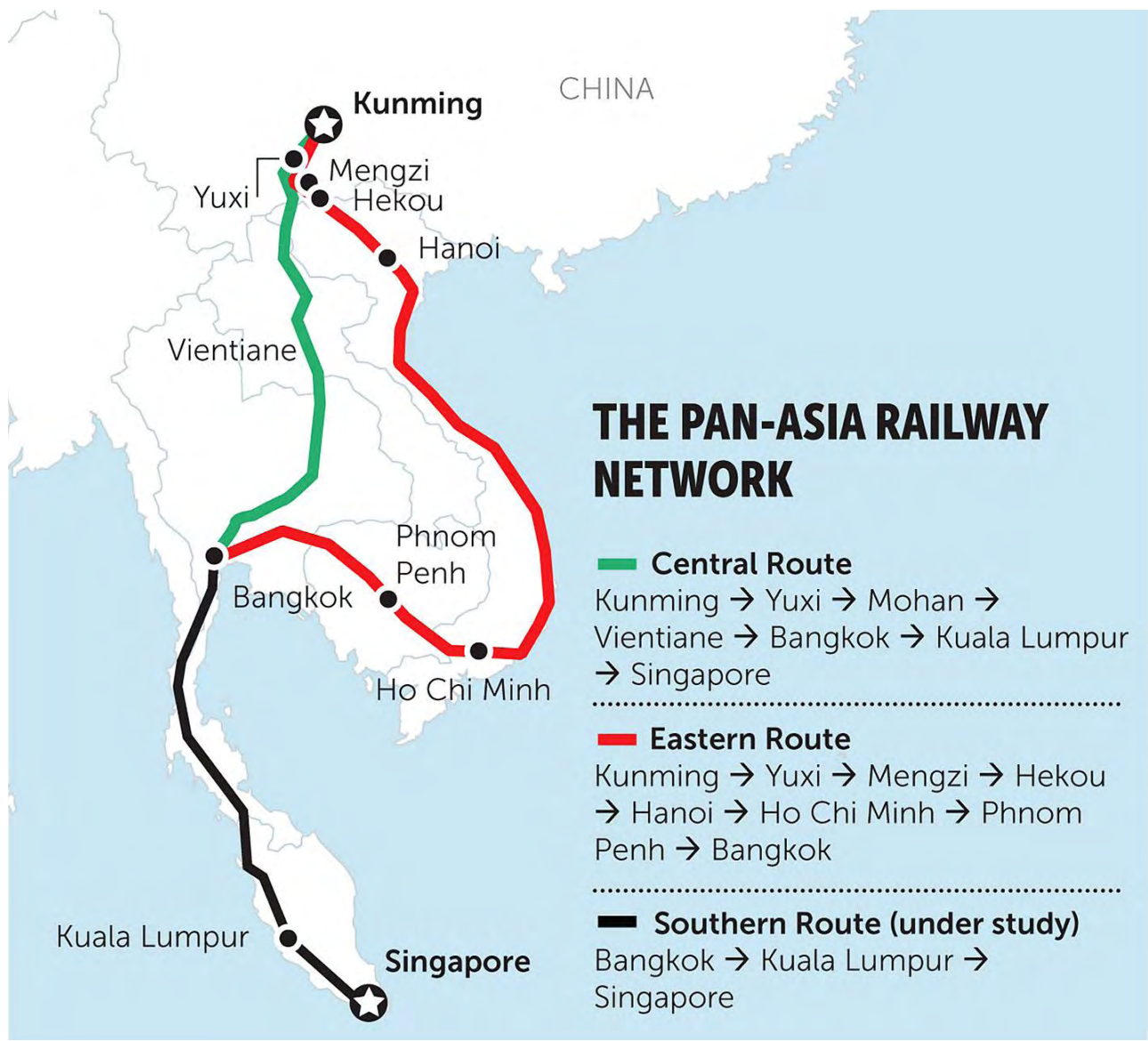


The governments of the two countries set up a joint venture company known as "Lao-China Railway Company" with China holding a 70\% share and Laos being responsible for the remaining 30\% (SCMP, 2019). The financial background was not clear for months until the Railway Company shared some news about it. According to Nikkei Asian Review, the project requires contributions of 715 million USD from Laos and 1.67 billion USD from China. Laos will finance 250 million USD of its share from the national budget and borrow the remaining 465 million USD from the Export-Import Bank of China at 2.3\% interest with a five-year grace period and 35year maturity (Nikkei, 2017). The paper also highlights that the report is not clear about the remaining $60 \%$ of the costs. It just says, it will be financed by Chinese Banks meaning that this amount also comes in the form of Chinese loans (Ibid).

With a total length of 414 kilometers, the single track (with a 1.435-metre standardgauge) rail network will consist of 32 stations. Over $62 \%$ of the track consists of bridges and tunnels because of the geographic conditions. The designed speed for passenger trains is $160 \mathrm{~km}^{5}$ per hour, for freight trains is $120 \mathrm{~km}$ per hour (The Laotian Times, 2017). The China-Laos railroad will connect and continue with the future railway in Thailand.

The Vientiane-Kunming link will cut the travelling time between the two cities from three days to several hours. This will enable investors to save time and money from lower transport costs, contributing to a boost in trade and people-to-people exchange between Laos and China.

Lao Minister of Public Works and Transport, Bounchanh Sinthavong said in April 2019 that the railway will benefit Lao PDR and Lao people, serving as a key momentum to push for greater advancement of commercial agricultural productivity in parallel with development of the trade and industrial sector in the country (LNA, 2019). Lao Railways' Director General, Somsana Ratsaphong said during the AsiaPacific Rail conference in Hong Kong in 2019 that the railway will boost tourism industry and bring about new developments along its route, particularly the new investment of industrial parks, hotels and other tourism related businesses (SCMP, 2019). The railway project will not only bring new technology to Laos but also encourage Lao people to boost their agricultural productivities for export to the Chinese market. According to feasibility studies and reports, the constructors expect "6.11 million passengers annually in the first few years of the railway's operation and 8.62 million passengers each year in the long term." (China Daily, 2017).

The construction of railways, including the China-Laos line, made it clear that China aims to engage with Southeast Asian nations since China actively takes part in such projects (Renliang, 2016). All these infrastructure schemes will not only bring China closer to ASEAN countries, but also offer opportunities and pose challenges for these countries including Laos. In fact, many Laotians are concerned that the railway will stimulate an influx not just of Chinese tourists but also investors, fearing that they will be allowed to buy land and other properties which will eventually put Laos closer into the orbit of China. Laotians also worry that local markets could be dumped with cheap products imported from countries across the region. But altogether, within ASEAN, Laos is still more optimistic about the Chinese 'intervention'. 


\section{Perceptions of ASEAN and Lao Residents on the BRI, China and Major Powers}

In 2018 the ASEAN Study Center and the ISEAS Yusof Ishak Institute conducted an online survey titled "State of Southeast Asia: 2019". The move aimed to seek views of Southeast Asian residents on regional affairs. Using the purposive sampling method, the survey collected views from a total of 1,008 Southeast Asian experts and stakeholders from the policy research, civil society, media and business communities (ASEAN-ISEAS, 2019:3). As a result of the survey, 45.4\% of respondents think that "China will become a revisionist power with an intent to turn Southeast Asia into its sphere of influence." (Ibid: 18). Laotians were the least critical after Myanmar respondents, only $24.1 \%$ of them shared the same view, $48.3 \%$ of them said (compared to the overall ASEAN $22.5 \%$ ) that "China will remain a status quo power and continue to support the existing regional order." (Ibid). $47 \%$ of the respondents said that BRI will "bring ASEAN member states closer into China's orbit" (compared to the Laotian 31\%). Lao experts dominantly $(75.9 \%)$ responded by saying: it will "benefit regional economic development and enhance ASEAN-China relations." (Ibid: 19).

When asked about which country/regional organisation has the most influence economically in Southeast Asia, 73.3\% said China (Laos: $82.8 \%$ ), and when they were asked about political and strategic influence, $45.2 \%$ answered with China, followed by the US with $30.5 \%$ (Laos: 41.4 and $20.7 \%$ respectively) (Ibid: 21-22). When asked about a possible debt-trap, citing Sri Lankan and Malaysian cases, $70 \%$ said that his/her "government should be cautious to avoid getting into unsustainable financial debts with China", but only $46.2 \%$ of the Laotians replied the same way, there $42.3 \%$ answered: "My view on the BRI's positive impact has not changed, as these experiences do not apply to my country" (Ibid: 20).

\section{Can Laos Benefit from the Chinese Presence and the BRI?}

Laos is located in-between growing economies (China, Vietnam, Thailand) and can become an interconnector, a bridge for these countries. China aims to use the ASEAN-China railway as a significant route for exporting its products to ASEAN markets due to cheaper transportation costs while ASEAN countries are looking for opportunities to penetrate Chinese markets. There is an opportunity for Laos to act as a distributor of goods and services by purchasing goods from neighbouring countries and exporting them to others. Nevertheless, Laos needs to focus on developing its human resources; training people how to do business and offering transit services. Laos also needs to frame promotion policies and create incentives to attract more investment in the agriculture sector for export while analyzing market demand in China and other ASEAN countries and trying to satisfy their needs. 
But the forecasts are not really beneficial for Laos. Major cities outside of Laos, like Bangkok, Hanoi, Kuala Lumpur and Singapore are expected to receive the greatest benefits from these railway infrastructure projects (Morris, 2019) and for Laos it will only bring a large amount of debt while providing a disproportionate economic benefit to China. This does not mean that Laos will not gain any benefit from the regional connectivity, but the main question raised is how the country can manage to repay its debts owed to China and what kinds of products does Laos plan to produce to export to regional markets.

In 2017, the two-way trade between China and Thailand reached USD 73.6 billion, and the two sides agreed to upgrade their cooperation into a comprehensive economic partnership in order to double the two-way trade value to USD 140 billion in 2021 (Bangkok Post, 2018). Coming from this, the railway might be designed to serve China's trade needs and benefit its economic relations with more relevant ASEAN economies. ${ }^{6}$

Eventually we can say Laos needs to invest in education and support its entrepreneurs and companies through creating a stable and transparent legal and economic environment. This is because the infrastructure investments alone will not deliver the hoped benefits without Lao actors being able to enjoy its gains. Besides this, it is also important to note, probably Laos had little room for manoeuvre and had no choice but to accept these investments, especially since the region cannot escape from the growing Chinese activity.

If they want to serve as a regional hub, they need such investments and they need investors - and China is ready for such moves, which is essential in times of global economic turbulence. A close cooperation with China and the infrastructure can actually be beneficial for them because of the US-China trade war as well: multinational corporations forced to relocate their production base from China might end up in ASEAN nations (and Vietnam is already active in this field) and good connectivity can put Laos in position as well.

\section{The Threats of These Projects}

The construction of Vientiane-Kunming rail line is a landmark. However, the railroad requires over 4,400 families in 167 villages of 13 districts to leave their homes to make way for construction. More than 3,830 hectares of land and 3,346 buildings along with crops, fruit trees, fences and forestry are affected by the project. (ANN, 2018). Many villagers fear that compensation offered by the government will be lower than the actual value of their properties. The total value of the project compensation is estimated to cost about USD 297.73 million, but due to financial difficulties, as of the summer of 2020 , many villagers have yet to receive any compensation.

With regards to the labour force employed for the railway, the Lao government struggles to ensure that the project will generate as many jobs as possible for Lao people. Unfortunately, China employs its own labour force, claiming that Lao people are unskilled hence the necessity for the railway construction companies 
to import Chinese workers. By December 2018, a total of 17,115 workers were employed for construction of the railway tracks, tunnels and other necessities. Only 4,032 Lao workers were employed in the project, the rest of them were dominantly Chinese nationals (Jarabejo, 2019).

Laos also struggles to develop a skilled labor force to respond to the needs of train operation and services. There is the concern that the railway will put greater economic pressure on domestic industries by opening up the local market to Chinese imports. However, if local producers are not prepared well enough to compete with those of wider Asian region, the railway will only bring tougher competition into the domestic market. The main problem in Lao PDR is that the downsides and risks regarding the railway have not been explicitly discussed, particularly issues relating to governance, corruption, pollution and adverse social impacts.

A further threat is connected to the financial aspects of such projects, and it is not just about the railway: how the country will be able to pay back those loans. In 2015 , the outstanding public debt was recorded at around $66 \%$ of the GDP, rising from 62.5\% in 2013 (World Bank, 2017: 24-26). According to an IMF report, almost $65 \%$ of the total external debt in Laos is owed to bilateral lenders, particularly China (IMF, 2019: 6). As a result, the fiscal space of the country for future borrowing has considerably narrowed. Despite rising public debt, Laos continues to borrow more money from development partners to finance its large infrastructure projects. For instance, the total investment cost of the China-Laos railway project is more than $30 \%$ of the country's annual GDP. The International Monetary Fund has warned that the railway project ramps up pressures on Laos' external debt, forcing the country to further seek for more loans to repay interest and principals as well as to fund other infrastructure projects (Ibid).

The more Laos is indebted to China, the more pressure the country will face as Beijing can use its power to influence the policy-making process in Laos in exchange for FDI and Official Development Assistance (ODA). The so-called debtdiplomacy, where the creditor country intentionally offers loans to struggling host states in need for the purpose of extracting economic or political concessions, is an agenda in Southeast Asia as well - as we could see from the ASEAN report. Although in this case, both sides are refusing to talk about possible financial difficulties, it could take decades for the Lao government to make a profit from the railway project and it is unclear whether the calculation of the railway's future profits is accurate based on the real and verified data and whether the railway can generate sufficient income to repay China's loan or not. Laos needs to have a plan $B$ to respond to economic shocks if the country wants to avoid defaulting on its debt repayment. In Malaysia, when Mohamed Mahathir became the Prime Minister in 2018, he cancelled the Chinese-funded East Coast Rail Link Project which was approved by the Najib Razak administration. He told China that the value of the project was too high, and Malaysia was unable to repay it and asked to renegotiate the deals with China. As a result of their renegotiation, China agreed to reduce the costs of the first two phases of the railway by over 30\% from USD 15.8 billion to USD 10.7 billion (ASEAN Today, 2019). However, Laos has not challenged or asked for a renegotiation of the deals with China. 


\section{The Chinese Position}

China has multiple considerations regarding the BRI and its infrastructure investments and loans. Besides the obvious benefits of the Initiative, how they can gain outlets for its SOEs and its economy through attracting host countries, Laos offers further gains. These include: regional and international support of the country on a global and on an ASEAN level by the Lao government, access to the natural resources of Laos and, through these projects, they can get closer to further ASEAN member states and economies. Laos, with its geostrategic position, can serve as a gate, a bridge and also as a buffer zone which gives Beijing an opportunity to create and maintain a close control (and domination) over the Southeast Asian region.

When it is about the loans and the threat of Laos not being able to pay those back, Beijing does not worry that much. The natural resources are the guarantee for them. For instance, when Laos failed to repay an USD 80 million loan provided by China to construct the National Stadium for the Southeast Asian Games in 2009, the Lao government granted a long-term land concession project to the contracted Chinese enterprise over an area of 300 hectares, instead of repaying the debt to China (The Laotian Times, 2017). As the Lao government's measures to service its debts remain unclear, China has seen long-term benefits from giving a huge amount of loans to Laos.

\section{"Connectivity" is the Keyword}

Laos depends mostly on its neighbours, mainly Thailand, for seaport services. The country's road network "represents $98 \%$ of total passenger-kilometers travelled, and $86 \%$ of freight moved in the country" (Xinhua, 2017). One of the main challenges for Laos is that its road network lacks proper maintenance and is far from the required quality due to limited funding. Apart from the China-Laos railway, the Lao government unveiled its plan to build expressways and motorways stretching over $1,700 \mathrm{~km}$. These roads will connect Laos with China, Thailand and Vietnam as Laos aims to serve as a regional hub of mutual connectivity between China and other ASEAN neighbours.

- The first expressway linking the Lao capital of Vientiane to the northern tourist town of VangVieng has already commenced construction. The USD 1.3 billion project will run $113.5 \mathrm{~km}$ northwards from the capital and is scheduled for completion in 2021 (Bangkok Post, 2019a). The Vientiane-Vangvieng expressway is part of a larger future project that will connect the Lao capital to Boten in Luang Namtha province, near the Chinese border.

- Meanwhile, the $585 \mathrm{~km}$ long expressway from Vientiane to Pakxe city in southern Laos is in the process of a feasibility study and project design which is carried out by Lao and Chinese companies (ASEAN Travel, 2017). 
- Furthermore, a feasibility study is being conducted to develop a capital-tocapital motorway, which stretches $707 \mathrm{~km}$ from Vientiane to Hanoi, Vietnam, with an estimated cost of the project construction amounting to USD 4.5 billion. In addition, the government of Laos and Vietnam signed an agreement earlier in 2019 to build a railway linking Vientiane to the Vung Ang seaport in Vietnam over a distance of 555 kilometers, which will be another significant component of the regional trade route (Bangkok Post, 2019a).

- Another railroad project under construction will connect Savannakhet province in the central part of Laos to Vietnam, known as Savannakhet-Lao Bao Railway, the expected completion date is the end of 2020 (Reconnecting Asia, 2020).

If all transportation infrastructure projects will be completed, Laos can become both a hub and an interconnector for the regional actors and, with the connected services and transfers, it can benefit from the regional economic and trade relations. However, it is still required that the country's entrepreneurs, companies and actors are prepared for this role. Otherwise, these further investments, the Vietnam link as well, might just further expose the underdeveloped economic environment of Laos to the international actors. That said, the main challenge right now is for Laos to balance its infrastructure needs and debt management to avoid a financial crisis in the future.

\section{Conclusion and Recommendations}

We can conclude that China uses its economic influence to achieve its strategic and geopolitical goals. From an economic perspective, the BRI provides opportunities for international cooperation and connectivity, serving the Chinese needs. As we could see in the case of Laos, these projects might fit the interests of the affected countries as well. Although, through these projects, and especially through the financial-loan constructions, Beijing might influence the decision-making process of the host countries or gain even more benefits. Due to its increasing financial dependency on China, Laos is on the verge of indebtedness and, if these infrastructure projects will not deliver the hoped for benefits, the country might find itself fully exposed to the Chinese intentions. While there are doubts about the cooperation, the Lao government still firmly believes that the initiative (and especially the railway and further infrastructure projects) will help the country to overcome its geographic disadvantages and they can turn themselves into an interconnector and a regional economic hub for the region.

In the paper a number of problems have been identified which need to be promptly addressed so the key recommendations can be summarized as follows:

- The policy formulation of the BRI and its activities are mostly driven by China and although we could see that the host countries' interests might meet with these plans, a more transparent public-driven process is required where experts, scholars and entrepreneurs can sound their opinions about the planned projects. 
- The Lao government needs to invest more in its education sector to produce more skilled human resources to satisfy the national development needs and it should also push for a more active participation of the Lao workforce in BRI projects.

- Infrastructure is essential for Laos to transform itself from a landlocked to a land-linked country, but the government needs to diversify its development partners and closely monitor and control the indebtedness.

- The government needs to invest more in research programmes, particularly in the area of agriculture and transit services and focus actively on the tourism sector if Laos wants to serve as a regional land bridge and become the economic hub of the region.

\section{Bibliography}

ANN. (2018). Compensation payments for Laos-China railway slated for completion in 2019. Asia News Network. Retrieved from http://www. asianews.eu/content/compensation-payments-laos-china-railway-slatedcompletion-2019-85946.

ASEAN-ISEAS. (2019). State of Southeast Asia: 2019. ASEAN Studies Centre - ISEAS - Yusof Ishak Institute. Retrieved from https://www.iseas.edu.sg/ images/pdf/TheStateofSEASurveyReport_2019.pdf

ASEAN Today. (2019). Where does Malaysia's renegotiated ECRL deal leave China and its Belt and Road Initiative? Retrieved from https://www. aseantoday.com/2019/04/where-does-malaysias-renegotiated-ecrl-dealleave-china-and-its-belt-and-road-initiative/.

ASEAN Travel. (2017). Expressway Planned between Vientiane and Pakse in Laos. Retrieved from asean.travel/2017/02/10/expressway-plannedvientiane-pakse-laos/

Bangkok Post. (2013). Logistics and the Lao economy: Linking up and reaching out. Retrieved from https://www.bangkokpost.com/business/357791/ logistics-and-the-lao-economy-linking-up-and-reaching-out.

Bangkok Post. (2018). Thai-China trade pact signed. Retrieved from https:// www.bangkokpost.com/business/1572030/thai-china-trade-pact-signed.

Bangkok Post. (2019a). Laos highway projects to boost ASEAN travel. Retrieved from https://www.bangkokpost.com/thailand/general/1708174/ laos-highway-projects-to-boost-asean-travel.

Bangkok Post. (2019b). https://www.bangkokpost.com/thailand/ general/1708122/from-bangkok-to-beijing\#group=nogroup\&photo=1

China Daily. (2017). Laying tracks for change in Laos. Retrieved from https:// www.chinadailyhk.com/articles/2/16/73/1507004778156.html.

Comtrade. (2020). UN Comtrade Database. Retrieved from https://comtrade.un.org. 
Globe. (2018). Laos gambles on becoming 'battery of Southeast Asia'. Retrieved from https://southeastasiaglobe.com/laos-gambles-on-becoming-battery-ofsoutheast-asia/.

IMF. (2019). Lao PDR. IMF Country Report No. 19/267. Retrieved from https://www. imf.org/en/Publications/CR/Issues/2019/08/08/Lao-Peoples-DemocraticRepublic-2019-Article-IV-Consultation-Press-Release-Staff-Report-48577.

Jarabejo, J. (2019). Urbanization in Southeast Asia: Field Notes from Laos. Retrieved from datadrivenlab.org/data/urbanization-in-southeast-asia-fieldnotes-from-laos/

Liu, Q., Pagano, A. M., Sánchez, O. V. \& Tapiero, E. (2018). China's One Belt and One Road: Implications for the Americas with Emphasis on the US and Panama. Retrieved from https://editorialexpress.com/cgi-bin/conference/ download.cgi?db_name=TRF18\&paper_id=6.

LNA. (2019). President Bounnhang to Attend 2nd BRF In Beijing. Lao News Agency. Retrieved from http://kpl.gov.la/En/Detail.aspx?id=45542.

McGrain, J. (2014). Laos: Investment Potential and Economic Challenges. Centre for Strategic and International Studies. Retrieved from https://www.cogitasia. com/laos-investment-potential-and-economic-challenges/.

Morris, S. (2019). The Kunming-Vientiane Railway: The Economic, Procurement, Labor, and Safeguards Dimensions of a Chinese Belt and Road Project. CGD Policy Paper. No. 142. Center for Global Development. Retrieved from https://www.cgdev.org/publication/kunming-vientiane-railway-economicprocurement-labor-and-safeguards-dimensions-chinese.

MYHSR. (2017). Asia's future cities: High-speed rail on track to connect Vientiane to the region. Retrieved from https://www.myhsr.com.my/resource/newsroom/ asias-future-cities-high-speed-rail-on-track-to-connect-vientiane-to-theregion.

Nikkei. (2017). Land-locked Laos on track for controversial China rail link. Retrieved from https://asia.nikkei.com/Politics-Economy/International-Relations/Landlocked-Laos-on-track-for-controversial-China-rail-link.

Phommouny, P. (2019). The Impact of China's Foreign Direct Investment on Economic Growth of Lao PDR. North American Academic Research. Volume 2, Issue 11. pp. 183-195.

Reconnecting Asia. (2020). Savannakhet-Lao Bao Railway (Construction). Retrieved from https://reconnectingasia.csis.org/database/projects/savannakhetlao-baorailway-project-220-km/9306d622-4f8d-478c-a027-fa50ef9b7b29/

Renliang, L. (2016). Dancing with the Dragon: The Trans-Asia Railway and its Impact on Thailand. ISEAS-Yusof Ishak Institute. Retrieved from https:// www.iseas.edu.sg/images/pdf/ISEAS_Perspective_2016_9.pdf.

SCMP. (2019). China's US $\$ 7$ billion railway link to Laos is almost half done, on schedule to begin service in 2021. South China Morning Post. Retrieved from https://www.scmp.com/business/banking-finance/article/3002518/chinasus7-billion-railway-link-laos-almost-half-done. 
The Laotian Times. (2017). Everything You Need to Know about the Laos-China Railway. Retrieved from https://laotiantimes.com/2017/02/20/everythingyou-need-to-know-laos-china-railway/.

Tuo, Z., Hui, Y., \&Zhongxia, R. (2018). ReportonChina-LaosCooperationOpportunities under the Belt and Road Initiative. China Economic Information Service. Retrieved from http://upload.silkroad.news.cn/2018/0208/1518061660339.pdf.

UN. (2015). Country Analysis Report: Lao PDR. Analysis to inform Lao PDR-UN Partnership Framework (2017-2021). United Nations. Retrieved from http:// www.la.one.un.org/images/Country_Analysis_Report_Lao_PDR.pdf.

World Bank. (2017). Lao Economic Monitor. Challenges in promoting more inclusive growth and share prosperity. Retrieved from http://documents. worldbank.org/curated/en/334091494603178415/pdf/115000-WP-P158830PUBLIC-LaoEconomicMonitorAprilChallengesinpromotingmoreinclusivegro wthandsharedprosperity.pdf.

World Bank. (2018). Belt and Road Initiative. Bank Group Report. Retrieved from https://www.worldbank.org/en/topic/regional-integration/brief/belt-and-roadinitiative

World Bank. (2019). Ease of Doing Business Rankings. Doing Business. Retrieved from https://www.doingbusiness.org/en/rankings.

WFP. (2017). Lao People's Democratic Republic Country Strategic Plan (20172021). World Food Programme. Retrieved from https://documents.wfp.org/ stellent/groups/public/documents/eb/wfp289381.pdf.

Xinhua. (2017). Laos to promote transport infrastructure. Retrieved from www. xinhuanet.com//english/2017-03/14/c_136128333.htm.

Xinhua. (2020). Laos' foreign tourist arrivals up 9 pct in 2019. Retrieved from www.xinhuanet.com/english/2020-01/08/c_138688181.htm

\section{Endnotes}

1 EFOP-3.6.3-VEKOP-16-2017-00007- Young researchers from talented students - Fostering scientific careers in higher education

2 For years there were plans for a Western route as well through Myanmar, but lately there is no information about that project.

3 "According to a recent study by the Japan External Trade Organization, logistics costs in Laos are as high as double those of other countries in the Association of Southeast Asian Nations, likely due to poor basic infrastructure. The cost in Laos works out at 2.50 USD per km, while in Thailand it only costs 1.10 USD per km, the study showed." (China Daily, 2017). 
4 Bangkok Post, 2019b

5 Early ideas were about a high-speed railway connection, but probably the financial conditions changed those plans.

6 It was already visible, that Thailand and China are active about their cooperation: "Already one Lao industry, trucking, has seen a loss in opportunity due to new regulations and procedures that will speed transshipment and customs clearance. A 2011 memorandum of understanding between Thailand and China allows pre-inspected fruits to be transported from Chiang Khong district in Thailand via Laos uninterruptedly to the border crossing in Mohan, in China's Yunnan Province, without being reloaded onto Lao trucks. The agreement has helped boost overland shipments of fruit from Thailand to China to a $45 \%$ annual growth rate, up from an annual average of $20 \%$ before, but Lao truckers do not benefit. This case underscores the importance for Laos of building up its own production capacities." (Bangkok Post, 2013). 